\title{
Effectiveness of irradiation treatment in eliminating $E$. coli 0157:H7 and Salmonella in dried organic herb samples intended for use in blended tea
}

\author{
Sharmin Zaman ${ }^{1}$, Md. Khorshed Alam², Md. Firoz Mortuza ${ }^{2}$, Md. Latiful Bari ${ }^{1, ~ * ~}$ \\ ${ }^{1}$ Center for Advanced Research in Sciences, University of Dhaka, Dhaka-1000, Bangladesh \\ ${ }^{2}$ Institute of Food and Radiation Biology, Bangladesh Atomic Energy Commission, Savar, Dhaka, Bangladesh
}

Email address:

sharmin_micro@yahoo.com (S.Zaman),alammk@hotmail.com (K. Alam), latiful@du.ac.bd (M. L. Bari), firozmortuza@gmail.com (M. F Mortuza)

\section{To cite this article:}

Sharmin Zaman, Md. Khorshed Alam, Md. Firoz Mortuza, Md. Latiful Bari. Effectiveness of Irradiation Treatment in Eliminating E. coli O157:H7 and Salmonella in Dried Organic Herb Samples Intended for Use in Blended Tea. Journal of Food and Nutrition Sciences. Special Issue: Food Processing and Food Quality. Vol. 3, No. 1-2, 2015, pp. 165-170. doi: 10.11648/j.jfns.s.2015030102.42

\begin{abstract}
Blended tea with different herbs, seeds and dehydrated vegetable substances bring a world of flavours, aromas and colours to tea. Tea is usually made with dried tea leaves, or blended with other dried herbs and pouring boiling water over the leaves and letting them stay for a few minutes and then sip. This study was done to evaluate the microbial contamination of dried organic lemongrass, mint and jasmine samples intended to prepare flavoured tea and also to see the effect of gamma irradiation in inactivating microorganisms in dried organic herbs (lemongrass, mint and jasmine) samples intended to prepare flavoured tea. Presence of higher number of generic E. coli and pathogenic E. coli O157:H7 in dried organic lemongrass, mint, and jasmine samples, and blended tea samples were observed. No Salmonella was detected in dried lemongrass sample; however, presence of Salmonella was evident in mint and jasmine samples. Application of 2.0 kGy irradiation dose was able to successfully eliminate the pathogenic E. coli O157:H7 and Salmonella in lemongrass, mint and jasmine samples. In addition, the aerobic bacterial count was also reduced to $<100 \mathrm{CFU} / \mathrm{g}$ in dried lemongrass or other tea samples. This finding suggested that application of $2.0 \mathrm{kGy}$ dose of irradiation could successfully eliminate the pathogens and provide safe food with lower bacterial content compared to non-irradiated herbs for human consumption.
\end{abstract}

Keywords: Organic Herbs, Lemongrass, Mint, Jasmine, E. coli O157:H7, Salmonella, Irradiation

\section{Introduction}

Lemongrass (Cymbopogan flexuosus, family: Poaceae), mint and jasmine are aromatic medicinal plant which grows in many parts of tropical and sub-tropical South East Asia and Africa [6]. These fresh cut herbs can be dried easily and preserved without significantly losing flavour or nutritional properties. However, these dried herbs (lemongrasses, mint and jasmine) are blended with tea leaves to make flavoured tea and are readily available worldwide.

These fresh herbs and leafy greens are potential transmission sources of enteropathogens, in a recent report from WHO/FAO on microbiological hazards in fresh fruits and vegetables [9]. It was stated that leafy green vegetables (including fresh herbs) "currently presented the greatest concern in terms of microbiological hazards." This is because these products are grown and exported in large volumes, and they have been associated with many foodborne disease outbreaks affecting considerable numbers of people. Additionally, the production chain for leafy greens is highly complex. The microflora on these vegetables at harvest reflects the environment in which they are grown, if the temperature and humidity is relatively high and the occurrence of enteropathogenic bacteria in this environment might be considerable [2]. During cultivation, use of contaminated water for irrigation, application of biocides, and refreshing or washing of harvested crops, is a potential source of contamination. Contamination from contact with fresh manure used as fertilizer cannot be excluded. Heavy rainfall may also lead to faecal contamination from the environment. Direct sunshine will most likely have a disinfection effect, but if the plants are irrigated until harvest and the production hygiene during and post-harvest is inadequate, there is a relatively high likelihood that the fresh 
herbs and leafy greens may be faecally contaminated. These fresh herbs and leafy greens and their products was found contaminated with pathogenic bacteria such as Staphylococcus aureus, Escherichia coli, Salmonella enterica serovar Typhi, Shigella spp, Bacillus spp. amongst others that present serious health hazards [3, 4].

In 2005, the Norwegian Food Safety Authority (Mattilsynet) conducted an ad hoc survey of 162 fresh herbs and green or leafy vegetables products, from South East Asia, and found that $28 \%$ were contaminated with Salmonella, and $35 \%$ with E. coli at $>100 \mathrm{CFU/gram} \mathrm{[8].} \mathrm{Microbiological}$ contamination of these herbs triggered serious concern in the production of therapeutical medicine preparations. Therefore, there was a need to improve the microbiological quality of fresh/dried herbs using different decontamination technology and the decontamination treatments should be fast and effective against all microorganisms [14].

The conventional methods of decontamination were fumigation with gaseous ethylene oxide or methyl bromide, which are now prohibited or being increasingly restricted in most advanced countries for health, environmental or occupational safety reasons. [11, 12], thus irradiation technique was chosen to replace them. The use of ionizing radiation as a physical method of microbiological decontamination of food, including spices and herbs, was approved by the Codex Alimentarius Commission - CDC. The experts agreed that radiation does not cause any toxicological changes or activation of irradiated food products; therefore, toxicological tests for food treated by this method are not needed. Gamma rays or X-rays up to 5 $\mathrm{MeV}$ and electrons up to $10 \mathrm{MeV}$ energy can be used for this purposes and dose up to $10 \mathrm{kGy}$ is allowed [20]. The content of essential biologically active substances such as essential oils, flavonoids, glycosides, anthocyanins, anthra-compounds, polyphenolic acids, triterpene saponins, oleanosides and plants mucus did not change significantly after irradiation. In addition, the sensory properties of most spices are well maintained between 7.5-15 kGy. Research clearly indicates that irradiation maintains the sensory properties of spices, herbs and vegetable seasonings better than EtO treatment [7]. Even though, irradiation decontamination is technically feasible, very effective and environment friendly process, but received less attention for fresh/dried herbs. The objectives of this study were to evaluate the microbial distribution in the production of organic lemongrass, mint and Jasmine and to evaluate the effectiveness of irradiation treatments in eliminating pathogenic E. coli $\mathrm{O} 157: \mathrm{H} 7$ and Salmonella in the dried organic herbs to ensure food safety.

\section{Materials and Methods}

\subsection{Sample Collection}

Herb samples include, lemongrass, mint, neem and jasmine were brought from an organic farm of Northern Bangladesh in between May 15 - July 30, 2013. All the samples were transported to the Food Analysis and Research
Laboratory, Center for Advanced Research in Sciences (CARS) of University of Dhaka using cool box at earliest convenience for processing and further analysis. All the microbial analysis was carried out according to the standard methods described in FDA Bacteriological Analytical Manual.

\subsection{Total Aerobic Count and Total Coliform Count}

Twenty five (25) $\mathrm{g}$ of each sample were homogenized in $225 \mathrm{~mL}$ of saline water $(0.85 \% \mathrm{NaCl})$. Decimal dilution was prepared upto $10^{-6}$ and appropriate dilutions were spread plated on Tryptic soy agar (Oxoid Ltd., Hampshire, England) and incubated at $35^{\circ} \mathrm{C}$ for $24 \mathrm{hr}$ for total aerobic bacterial count and on Mac Conkey agar (Oxoid Ltd., Hampshire, England) with incubation at $35^{\circ} \mathrm{C}$ and $42^{\circ} \mathrm{C}$ for 24 hours for total coliform count. Total aerobic count indicates the quality and shelf life of the products and total coliform count indicates the unhygienic condition of the food preparation surfaces.

\subsection{Escherichia Coli, Feceal Coliform Bacteria}

Twenty five (25) g of each sample were homogenized in $225 \mathrm{~mL}$ Enterobacteria enrichment broth-Mossel preenrichment medium (Oxoid Ltd., Hampshire, England) and incubated at $35^{\circ} \mathrm{C}$ for 20 hours. One $\mathrm{mL}$ of pre-enriched cultures were mixed with nine $\mathrm{mL}$ of $2 \mathrm{x}$ EC medium (Nissui Co., Ltd., Tokyo, Japan) and incubated at $35^{\circ} \mathrm{C}$ for 20 hours. To confirm the presence of fecal coliform, one loopful of the culture was inoculated into $10 \mathrm{~mL} 1 \mathrm{x}$ EC medium with Durham fermentation tube and incubated at $42^{\circ} \mathrm{C}$ for 20 hours. Gas production in the tube indicates the presence of fecal coliform. To isolate $E$. coli, one loopful of gas produced 1x EC culture broth was streaked on EMB agar plate (Nissui Co., Ltd., Tokyo, Japan) and developed typical colonies were then confirmed using biochemical characterization (IMViC) and API 20E kit (bioMérieux, city, NC, USA). Presence of $E$. coli or fecal coliform bacteria indicates that the food is somehow contaminated with fecal matters.

\subsection{Escherichia Coli O157, O111, 026}

Twenty five (25) $\mathrm{g}$ of each samples were homogenized in $225 \mathrm{~mL}$ mEC medium (Nissui Co., Ltd., Tokyo, Japan) and incubated at $42^{\circ} \mathrm{C}$ for 20 hours. The enriched cultures were streaked in Sorbitol MacConkey agar (Oxoid Ltd., Hampshire, England) complemented with Cefixime and potassium tellurite supplement (Fluka, Sigma-Aldrich, Banglore, India) and characteristics colonies were subjected to biochemical tests (IMViC). Biochemically confirmed isolates were screened through Rainbow agar (Biolog, France) and CHROM agar (Kanto Co. Ltd., Kyoto, Japan). Then the colonies which gave characteristic color were serotyped by $\mathrm{O} 157, \mathrm{O} 111$ and $\mathrm{O} 26$ specific antisera. Then the isolates were tested for stxland stx2 by NH-Immunochromato VT1/2 and by PCR using primer 5'-CAGTTAATGTGGTGGCGAAGG3' and 5'-CACCAGACAAATGTAACCGCTC-3' for stx 1 and 5'-ATCCTATTCCCGGGAGTTTACG-3' and 5'GCGTCATCGTATACACAGGAGC-3' for stx2 [21]. 


\subsection{Salmonella spp.}

Twenty five (25) g of each sample were homogenized in $225 \mathrm{~mL}$ of buffered peptone water (Merck, Darmstadt, Germany) and incubated at $35^{\circ} \mathrm{C}$ for 20 hours. One $\mathrm{mL}$ preenrichment cultures were mixed with nine $\mathrm{mL}$ of Hanja Tetrathionate Broth (Eiken Chemical Co. Ltd., Tokyo, Japan) and incubated at $35^{\circ} \mathrm{C}$ for $20 \mathrm{hrs}$ and nine $\mathrm{mL}$ of RappaportVassiliadis Broth (Eiken Chemical Co. Ltd., Tokyo, Japan) and incubated at $42^{\circ} \mathrm{C}$ for $20 \mathrm{hrs}$. Then the broth the culture broths were streaked into DHL and MLCB and characteristics colony were gone through biochemical tests (TSI and LIM). Biochemically confirmed isolates were reconfirmed using Salmonella LA latex agglutination test and API 20E kits.

\subsection{Irradiation Treatment}

Irradiation of the samples was carried out by using Cobalt60 Panoramic Research Irradiator of Institute of Food and Radiation Biology (IFRB), Atomic Energy Research Establishment (AERE), Bangladesh Atomic Energy Commission, Bangladesh. The activity of the irradiator was $38.53 \mathrm{kCi}$ on the date of irradiation of these samples. Primarily, measurement of dose-rate was performed by Fricke dosimetry system. Fricke dosimeters were prepared following standard protocols [1]; by dissolving $0.392 \mathrm{~g}$ of ferrous ammonium sulphate $\left(\mathrm{Fe}\left(\mathrm{NH}_{4}\right)_{2}(\mathrm{SO} 4)_{2} \quad .6 \mathrm{H}_{2} \mathrm{O}\right)$ and $0.058 \mathrm{~g}$ of sodium chloride $(\mathrm{NaCl})$ in $12.5 \mathrm{~mL}$ of $0.4 \mathrm{~mol} / \mathrm{L}$ sulphuric acid $\left(\mathrm{H}_{2} \mathrm{SO}_{4}\right)$. The volume of the solution was made upto $1 \mathrm{~L}$ in a volumetric flask with $0.4 \mathrm{~mol} / \mathrm{L} \mathrm{H}_{2} \mathrm{SO}_{4}$ at $25^{\circ} \mathrm{C}$. Therefore, the concentrations of final solution were $0.001 \mathrm{M}$ ferrous ammonium sulphate, $0.001 \mathrm{M}$ sodium chloride and $0.4 \mathrm{~mol} / \mathrm{L}$ sulphuric acid.

Freshly prepared Fricke solution was poured in screw-cap vial and placed in the radiation field with samples for certain amount of time. After completion of irradiation, absorbance of irradiated Fricke solution was measured using spectrophotometer at $303 \mathrm{~nm}$; the unirradiated Fricke solution was used as control. The equation for calculating the absorbed dose in the Fricke dosimetric solution is

$$
\mathrm{D}=\mathrm{dA} \cdot \mathrm{N}_{\mathrm{A}} /(\rho \mathrm{G} \varepsilon \mathrm{d})
$$

Where,

$\mathrm{D}$ is the absorbed dose (Gy),

$\mathrm{dA}$ is the change in absorbance at $303 \mathrm{~nm}$ and $25^{\circ} \mathrm{C}$ (dimensionless), $\mathrm{dA}=\mathrm{Ai}-\mathrm{A} 0$, where $\mathrm{Ai}$ and $\mathrm{A} 0$ are the absorbances of the irradiated and non-irradiated solutions, respectively,

$\mathrm{N}_{\mathrm{A}}$ is Avogadro's number $\left(6.022 \times 1023 \mathrm{~mol}^{-1}\right)$,

$\rho$ is the density of the dosimetric solution $(1.024 \times 103$ $\mathrm{kg} / \mathrm{m}^{3}$ ),

$\mathrm{G}$ is the radiation chemical yield of $\mathrm{Fe}_{3+}$ ions $(9.74 \times 1017$ molecules/J) (This $G$ value is valid for electrons or photons in the energy range $0.5-16 \mathrm{MeV}$ at absorbed dose rates of less than $2 \times 107 \mathrm{~Gy} / \mathrm{s}$.),

$\varepsilon$ is the molar linear absorption coefficient (at $303 \mathrm{~nm}$ and $25^{\circ} \mathrm{C}$ ) as measured for the particular spectrophotometer (with a nominal value of $219 \mathrm{~m} 2 / \mathrm{mol}$ ), and

$\mathrm{d}$ is the optical path length in quartz cells, usually $\mathrm{d}=0.01$ $\mathrm{m}$.

For irradiation and absorption measurement temperature of $25^{\circ} \mathrm{C}$, with a $1.0 \mathrm{~cm}$ path length cuvette, and using the values of e and $\mathrm{G}$ given above, equation (1) reduces to

$$
\mathrm{D}_{\text {Fricke(Gy) }}=278 \mathrm{xdA} \text {. }
$$

The Fricke dosimetry system is primarily used in this experiment for dose mapping and determination of dose rate.

\subsection{Amber Perspex Dosimetry}

After selection of sample position and dose rate by Fricke dosimeters, Amber Perspex dosimeter was used for determination of delivered irradiation dose. The Amber Perspex dosimeter was prepared by Harwell Laboratory, Oxfordshire, United Kingdom. In this experiment, Amber Perspex Dosimeter Type 3042 was used which has a dose detection range between 1 to $30 \mathrm{kGy}$. Amber 3042 are made from radiation-sensitive poly-methylmethacrylate (PMMA) in the form of optically transparent pieces individually sealed in laminate sachets. They darken when irradiated, and the radiation-induced darkening, accurately measurable by means of a spectrophotometer, is a function of the radiation dose absorbed [13]. The absorbance $\left(A_{1}\right)$ is measured at 603 $\mathrm{nm}$ or $651 \mathrm{~nm}$. The thickness $\left(\mathrm{T}_{1}\right)$ of the dosimeter is also measured. Specific absorbance $\left(A_{1} / T_{1}\right)$ is calculated and the determination of delivered dose is done by using pre-existing graph/chart produced by Harwell Laboratory [13].

\subsection{Statistical Analysis}

Three samples of each category were taken from the same farm. Reported plate count data represented in tables were the $\log _{10}$ mean values \pm standard deviation of three individual trials, and each of these values being obtained from duplicated samples. Data were subjected to analysis of variance using the Microsoft Excel program (Redmond, Washington DC, USA). Significant differences in plate count data were established by the least-significant difference $(\mathrm{P}<0.05)$ at the $5 \%$ level of significance.

\section{Results and Discussion}

The search for healthy, safe, and sustainable food production has increased the consumption of organic fresh produce. These products should be free of pesticide residues and other synthetic substances commonly used in conventional agriculture, such as soluble fertilizers $[15,18]$. At the same time organic products have lower risks related to chemical contamination; however, several investigations have raised concerns related to the microbiological quality of these foods $[16,19]$. Among organic fresh produce, fresh and dried herbs stands out due to its flavours, aromas, colours and continual availability in the market as well as acceptability indistinctively of age or economic group of the population worldwide [17]. 
Thirteen categories of herbs and tea including black tea, blend tea, neem blend herbs, neem tea, mint (fresh and dry), jasmine (fresh \& dry), lemongrass \& lemongrass blend tea were analyzed for total aerobic population (TAB), total coliform population (TCC) and presence of E. coli, E. coli O157:H7 and Salmonella spp. Table 1 presents the results of the distribution of natural aerobic population, coliform population and presence of E. coli, E. coli $\mathrm{O} 157: \mathrm{H} 7$ and Salmonella spp in different fresh and dry herbs; water and manure soil. Higher aerobic bacterial count was recorded as $6.9 \log \mathrm{CFU} / \mathrm{g}$ in liker base tea samples and lowest aerobic count was recorded as $3.9 \mathrm{log} \mathrm{CFU} / \mathrm{g}$ in neem tea samples (Table 1). Among the herb and tea sample tested, neem tea and neem blended herbs were found microbiologically safe, because no coliform, fecal coliforms, E. coli, and salmonella was observed throughout the study. In contrast, jasmine, mint and tea blend with lemongrass was found contaminated and the presence of E. coli O157:H7 and Salmonella was recorded. Supply water used for irrigation, wash/rinse purpose, and compost used as fertilizer of soil were also analyzed. The water and composted manure was found heavily contaminated with enteric bacterial pathogens (Table 1). The total coliforms, E. coli and E. coli $\mathrm{O} 157: \mathrm{H} 7$ population was recorded as $5.0 \log \mathrm{CFU} / \mathrm{ml}, 4.7 \mathrm{CFU} / \mathrm{ml}$ and 4.2 CFU/ml, respectively. Salmonella spp. was not detected in the manure sample tested (Table 1). In this study, water for irrigation and washing/rinse purpose was contaminated with E. coli $\mathrm{O} 157 \mathrm{H} 7$, therefore; there is a risk of contamination of final products. Foodborne outbreaks involving green vegetables contaminated by water have been reported in several studies around the world [10,14]. Pathogenic bacteria such as E. coli $\mathrm{O} 157: \mathrm{H} 7$ are most often associated with outbreaks of waterborne diseases, resulting from inadequate treatment of water used for irrigation and washing of fresh produce [15-18]. Therefore, specific control measures should be should be developed in order to prevent final product contamination.

Table 1. Distribution of natural aerobic population, coliform population and presence of E. coli, E. coli O157:H7 and Salmonella spp in different fresh and dry herbs; water and manure soil ${ }^{a}$

\begin{tabular}{|c|c|c|c|c|c|c|}
\hline Herbs and tea Sample & $\begin{array}{l}\text { Total Viable count } \\
\text { (log CFU/g) }\end{array}$ & $\begin{array}{l}\text { Total Coliform count } \\
(\log \mathrm{CFU} / \mathrm{g}))\end{array}$ & $\begin{array}{l}\text { Total E.coli Count } \\
(\log \text { CFU/g) }\end{array}$ & $\begin{array}{l}\text { E.coli O157:H7 } \\
\text { counts (log CFU/g) }\end{array}$ & $\begin{array}{l}\text { Presence of } \\
\text { Salmonella Spp. }\end{array}$ & pH \\
\hline Black tea (Normal) & $5.9 \pm 0.08$ & $6.9 \pm 0.11$ & $4.7 \pm 0.14$ & $3.8 \pm 0.06$ & ND & 4.84 \\
\hline Blend tea & $6.4 \pm 0.11$ & $5.9 \pm 0.11$ & $4.5 \pm 0.11$ & $4.5 \pm 0.12$ & ND & 5.01 \\
\hline Black tea (Original) & $6.0 \pm 0.14$ & $6.0 \pm 0.34$ & $5.1 \pm 0.11$ & $4.6 \pm 0.11$ & ND & 5.40 \\
\hline Neem blend herbs & $4.1 \pm 0.15$ & $\mathrm{ND}^{*}$ & ND & ND & ND & 4.98 \\
\hline Neem Tea & $3.9 \pm 0.12$ & ND & ND & ND & ND & 5.04 \\
\hline Black tea (Premium) & $5.4 \pm 0.14$ & $4.1 \pm 0.21$ & $4.0 \pm 0.12$ & $3.2 \pm 0.11$ & ND & 5.10 \\
\hline liker base & $6.9 \pm 0.22$ & $6.2 \pm 0.22$ & $5.7 \pm 0.13$ & $5.2 \pm 0.15$ & ND & 7.13 \\
\hline Lemongrass & $5.9 \pm 0.11$ & $5.8 \pm 0.15$ & $5.8 \pm 0.23$ & $4.8 \pm 0.13$ & ND & 4.60 \\
\hline Lemongrass blended tea & $5.5 \pm 0.24$ & $5.0 \pm 0.09$ & $4.7 \pm 0.19$ & $4.4 \pm 0.11$ & $3.7 \pm 0.07$ & 6.00 \\
\hline Jasmine fresh & $5.7 \pm 0.11$ & $5.3 \pm 0.12$ & $5.1 \pm 0.11$ & $4.0 \pm 0.12$ & $1.0 \pm 0.09$ & 5.94 \\
\hline Jasmine dried & $5.4 \pm 0.13$ & $5.2 \pm 0.17$ & $5.0 \pm 0.11$ & $3.9 \pm 0.15$ & $1.0 \pm 0.12$ & 5.94 \\
\hline Mint fresh & $4.5 \pm 0.12$ & $4.4 \pm 0.19$ & $4.2 \pm 0.12$ & $3.2 \pm 0.11$ & $1.3 \pm 0.14$ & 5.99 \\
\hline Mint dried & $4.4 \pm 0.14$ & $3.5 \pm 0.23$ & $3.4 \pm 0.11$ & $2.4 \pm 0.12$ & ND & 5.94 \\
\hline Tap water & $3.5 \pm 0.13$ & $2.0 \pm 0.14$ & $1.8 \pm 0.11$ & $1.7 \pm 0.13$ & ND* & 6.60 \\
\hline Tank water & $6.0 \pm 0.13$ & $4.7 \pm 0.09$ & $3.9 \pm 0.11$ & $3.1 \pm 0.11$ & ND & 7.50 \\
\hline Ground water & $3.8 \pm 0.13$ & $3.4 \pm 0.07$ & $3.0 \pm 0.11$ & $2.1 \pm 0.12$ & ND & 6.50 \\
\hline Manure soil & $6.0 \pm 0.14$ & $5.8 \pm 0.09$ & $5.0 \pm 0.11$ & $4.7 \pm 0.11$ & ND & 7.80 \\
\hline
\end{tabular}

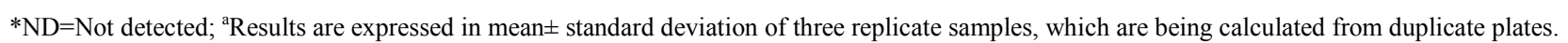

On the other hand, composted manure was analyzed and presence of higher number of coliforms $(5.8 \mathrm{log} \mathrm{CFU} / \mathrm{g}), E$. coli $(5.0 \log \mathrm{CFU} / \mathrm{g})$, and E. coli $\mathrm{O} 157: \mathrm{H} 7$ (4.7 $\log \mathrm{CFU} / \mathrm{g})$, was observed. Salmonella spp. was not detected in the compost samples (Table 1). Many published report indicated that the composting time and temperature of manure could effectively reduce microorganisms like E. coli, E. coli O157:H7, and Salmonella, routinely determined in fresh compost [9]. However, the organic fertilizer samples analyzed in the present study were above the limit (3.0 log $\mathrm{MPN} / \mathrm{g}$ ), indicating that the control of manure was not adequate.

Herbs producing under these conditions might possess opportunistic pathogens in fresh herbs and throughout the production process. These contaminations can be avoided if
GAP and good agriculture management had been in practices prior to production. For consumer, a common strategy to avoid foodborne disease is heating or cooking of potential risk products before consumption. However, this approach is not appropriate for the majority of fresh herbs and leafy greens that are mainly consumed raw, or added to food after the heat-treatment. Therefore, by considering the economic burden and consumers' safety, the contaminated dried herbs were evaluated to eliminate the pathogens using gamma irradiation treatment at very low doses ranging from 0 to 2.0 $\mathrm{kGy}$. We found that microbial reduction is dose dependant and at $2.0 \mathrm{kGy}$ dose of irradiation could effectively inactivate E. coli, E. coli O157:H7, and Salmonella without compromising its visual and color attributes. The other bacterial count was also below the permission level (Table 2). 
Cobalt-60 gamma source emits highly reactive ionizing radiation in the form of intense gamma rays and causes cellular damage which lead to cell death [5]. With increase radiation dose, DNA damage increases and subsequently, higher cell death may occur. Scientists worldwide have extensively researched the effects of irradiation on microbial populations in herbs, spices, vegetable seasonings and other dry ingredients. Irradiation is a well-established and exceptionally effective process to control microorganisms in spices [20]. The effect of irradiation on the microbial contamination of herbs is dose dependent and the type of microorganism present. The effect of irradiation on microbial reduction is relatively linear; therefore, the end result depends on the initial contamination level. However, increased irradiation doses may affect the sensory qualities of the herbs, hence, it is important to use good agricultural and processing methods to ensure the cleanest and best quality ingredients from the start.

Table 2. Inactivation of E. coli O157:H7 and Salmonella spp using different doses of irradiation in various dried organic herbs samples.

\begin{tabular}{|c|c|c|c|c|c|}
\hline Treatment & $\begin{array}{l}\text { Total Viable count (log } \\
\text { CFU/g) }\end{array}$ & $\begin{array}{l}\text { Total Coliform count } \\
(\log \mathrm{CFU} / \mathrm{g}))\end{array}$ & $\begin{array}{l}\text { Total } E \text {. coli count } \\
(\log C F U / g)\end{array}$ & $\begin{array}{l}\text { E. coli } \mathrm{O} 157: \mathrm{H} 7 \text { counts } \\
(\log \mathrm{CFU} / \mathrm{g})\end{array}$ & $\begin{array}{l}\text { Salmonella spp. count (log } \\
\text { CFU/g) }\end{array}$ \\
\hline \multicolumn{6}{|c|}{ Dried lemongrass } \\
\hline 0 kGy & $5.5 \pm 0.24$ & $5.0 \pm 0.09$ & $4.7 \pm 0.19$ & $4.4 \pm 0.11$ & $3.7 \pm 0.07$ \\
\hline 0.5 & $5.0 \pm 0.05$ & $4.5 \pm 0.22$ & $4.3 \pm 0.62$ & $3.5 \pm 0.09$ & ND* \\
\hline 1.0 & $4.5 \pm 0.22$ & $3.8 \pm 0.57$ & $4.0 \pm 0.05$ & $2.6 \pm 0.63$ & ND \\
\hline 1.5 & $4.4 \pm 0.20$ & $3.3 \pm 0.22$ & $3.7 \pm 0.19$ & $2.4 \pm 0.04$ & ND \\
\hline 2.0 & $3.5 \pm 0.31$ & ND & ND & ND & ND \\
\hline 2.5 & $2.9 \pm 0.03$ & ND & ND & ND & ND \\
\hline 3.0 & $2.7 \pm 0.18$ & ND & ND & ND & ND \\
\hline 3.5 & $2.6 \pm 0,08$ & ND & ND & ND & ND \\
\hline 4.0 & $2.5 \pm 0.05$ & ND & ND & ND & ND \\
\hline 4.5 & $2.0 \pm 0.01$ & ND & ND & ND & ND \\
\hline 5.0 & $2.0 \pm 0.01$ & ND & ND & ND & ND \\
\hline \multicolumn{6}{|c|}{ Dried Jasmine } \\
\hline 0 kGy & $5.4 \pm 0.13$ & $5.2 \pm 0.17$ & $5.0 \pm 0.11$ & $3.9 \pm 0.15$ & $1.0 \pm 0.12$ \\
\hline 0.5 & $4.9 \pm 0.12$ & $3.3 \pm 0.07$ & $3.6 \pm 0.15$ & $2.6 \pm 0.12$ & ND \\
\hline 1.0 & $4.3 \pm 0.08$ & $2.8 \pm 0.05$ & $2.4 \pm 0.08$ & $2.1 \pm 0.07$ & ND \\
\hline 1.5 & $3.6 \pm 0.06$ & $1.0 \pm 0.01$ & $1.0 \pm 0.05$ & $1.0 \pm 0.03$ & ND \\
\hline 2.0 & $3.2 \pm 0.11$ & ND & ND & ND & ND \\
\hline 2.5 & $2.6 \pm 0.07$ & ND & ND & ND & ND \\
\hline 3.0 & $2.0 \pm 0.01$ & ND & ND & ND & ND \\
\hline 3.5 & $2.0 \pm 0.01$ & ND & ND & ND & ND \\
\hline 4.0 & $2.0 \pm 0.01$ & ND & ND & ND & ND \\
\hline 4.5 & $2.0 \pm 0.01$ & ND & ND & ND & ND \\
\hline 5.0 & $2.0 \pm 0.01$ & ND & ND & ND & ND \\
\hline \multicolumn{6}{|l|}{ Dried mint } \\
\hline $0 \mathrm{kGy}$ & $4.7 \pm 0.14$ & $3.5 \pm 0.23$ & $3.4 \pm 0.11$ & $2.4 \pm 0.12$ & ND \\
\hline 0.5 & $4.4 \pm 0.14$ & $2.1 \pm 0.17$ & $2.0 \pm 0.07$ & ND & \\
\hline 1.0 & $4.0 \pm 0.14$ & ND & ND & ND & ND \\
\hline 1.5 & $3.6 \pm 0.14$ & ND & ND & ND & ND \\
\hline 2.0 & $3.3 \pm 0.14$ & ND & ND & ND & ND \\
\hline 2.5 & $3.0 \pm 0.14$ & ND & ND & ND & ND \\
\hline 3.0 & $2.6 \pm 0.14$ & ND & ND & ND & ND \\
\hline 3.5 & $2.0 \pm 0.01$ & ND & ND & ND & ND \\
\hline 4.0 & $2.0 \pm 0.01$ & ND & ND & ND & ND \\
\hline 4.5 & $2.0 \pm 0.01$ & ND & ND & ND & ND \\
\hline 5.0 & $2.0 \pm 0.01$ & ND & ND & ND & ND \\
\hline
\end{tabular}

*ND=Not detected; ${ }^{\mathrm{a} R e s u l t s ~ a r e ~ e x p r e s s e d ~ i n ~ m e a n ~} \pm$ standard deviation of three replicate samples, which are being calculated from duplicate plates. 


\section{Conclusion}

The present study concludes that irradiation decontamination of organic herb is a safe and very effective method. The losses of the biologically active substances are lower than that of other decontamination methods.

\section{References}

[1] ASTM (American Society for Testing and Materials). (2000). Practice for using the Fricke Reference Standard Dosimetry System, ASTM E1026, Annual Book of ASTM Standards, Vol. 12.02, Philadelphia, PA. USA.

[2] Abadias, M., Usall, J., Anguera, M., Solsona, C., \& Viñas, I. (2008). Microbiological quality of fresh, minimally-processed fruit and vegetables, and sprouts from retail establishments. International Journal of Food Microbiology, 123(1-2), 121129.

[3] Abba, D., Inabo, H. I., Yakubu, S. E and Olonitola, O. S. (2009). Contamination of herbal medicinal products marketed in Kaduna Metropolis with selected pathogenic bacteria. African Journal of Traditional, Complimentary and Alternative Medicines. Vol.6 (1): 70- 77.

[4] Adeleye, I. A., Okogi, G. and Ojo, E.O. (2005). Microbial contamination of herbal preparations in Lagos, Nigeria. Journal of Health, Population and Nutrition. 23 (3): 296- 297.

[5] Bari, M. L., Nakauma, M., Todoriki, S., Vijay K. Juneja, Isshiki, K. and S. Kawamoto. (2005). Effectiveness of Irradiation Treatments in Killing Listeria monocytogenes on Fresh Vegetables at Refrigerated Temperature. J. Food Prot. $68: 318-323$

[6] Cymbopogon citratus (DC. ex Nees) Stapf. USDA, NRCS. 2008. The PLANTS Database. ( http://plants.usda.gov, 10 December 2008). National Plant Data Center, Baton Rouge, LA 70874-4490 USA.

[7] Esimone, C.O. Oleghe, P.O. and Ibezim, E.C. (2003). Effect of preservation agents on the microbial stability of some indigenous herbal preparations. Niger J. Pharm 34:37-42.

[8] Espen Rimstad (chair), E. Arne Høiby , Georg Kapperud, Jørgen Lassen, Bjørn Tore Lunestad, Truls Nesbakken, Karin Nygård, Ørjan Olsvik, Lucy Robertson, Michael Tranulis and Morten Tryland. (2008). Norwegian Scientific Committee for Food Safety Panel on Biological Hazards final report on Risk assessment of import and dissemination of intestinal pathogenic bacteria via fresh herbs and leafy vegetables from South-East Asia. ISBN: 978-82-8082-244-4 ; 07/111-final report, pages 2-32.

[9] FAO/WHO (2008) Microbiological hazards in fresh fruits and vegetables. Meeting Report. Microbiological Risk Assessment Series. Available at the following URL and accessed on
August 7, 2013. (http://www.fao.org/ag/agn/agns/jemra riskassessment freshp roduce_en.asp)

[10] Fischer-Arndt, M., Neuhoff, D., Tamm, L., \& Köpke, U., (2010). Effects of weed management practices on enteric pathogen transfer into lettuce (Lactucasativa var. capitata). Food Control, 21(7), 1004-1010.

[11] Goodhead, D.T., Thacker, J., Cox, R., 1993. Effects of radiations of different qualities on cells: molecular mechanisms of damage and repair. Int. J. Radiat. Biol. 63, 543-546.

[12] Hsu WY, Simonne A, Jitareerat P, Marshall MR Jr.(2010). Low-dose irradiation improves microbial quality and shelf life of fresh mint (Mentha piperita L.) without compromising visual quality. J Food Sci. 75(4):M222-230. doi: 10.1111/j.1750-3841.2010.01568.x.

[13] Harwell Amber 3042 Dosimeters. Available at http://www.harwell-dosimeters.co.uk/harwell-amber-3042. Accessed on October 12, 2014.

[14] Ilic, S., Rajic, A., Britton, C., Grasso, E., Wilkens, W., Totton, S., LeJeune, J. (2012). A scoping study characterizing prevalence, risk factor and intervention research, published between 1990 and 2010, for microbial hazards in leafy green vegetables. Food Control, 23, 7-19.

[15] James, J. (2006). Microbial hazard identification in fresh fruits and vegetables. Dublin, Ireland: Wiley-Interscience.

[16] Johannessen, G. S. (2005). Use of manure in production of organic lettuce: Risk of transmission of pathogenic bacteria and bacteriological quality of the lettuce. Oslo, Belgic: Norwegian School of Veterinary Science.

[17] Oyetayo, V. O. (2008). Microbial load and Microbial property of two Nigeria herbal remedies. African Journal of Traditional, Complimentary and Alternative Medicines. Vol. 5(1): 74- 78.

[18] Olaimat, A. N., Holley, R. A. (2012) Factors influencing the microbial safety of fresh produce: a review. Journal of Food Protection, 32 (1), 1-19.

[19] Oliveira, A. B. A., Ritter. A. C., Tondo, E. C., \& Cardoso, M. R. de I. (2012). Comparison of different Washing and disinfection protocols used by Food Services in Southern Brazil for Lettuce (Lactuca sativa). Food and Nutrition Sciences, 3, 28-33.

[20] Subha Ganguly 1, Sunit Kumar Mukhopadhayay and Subhasish Biswas. (2012). Preservation of food items by irradiation process. International Journal of Chemical and Biochemical Sciences, 1:11-13

[21] Vidal, R., M. Vidal, R. Lagos, M. Levine and V. Prado. (2004) Multiplex PCR for diagnosis of enteric infections associated with diarrheagenic Escherichia coli. J. Clin. Microbiol. 42, 1787 